Egyptian Journal of Aquatic Biology \& Fisheries

Zoology Department, Faculty of Science,

Ain Shams University, Cairo, Egypt.

ISSN $1110-6131$

Vol. 24(1): 145 - 160 (2020)

www.ejabf.journals.ekb.eg

\title{
Assessment of Water and Sediments Pollution in Maruit Lake, Egypt
}

\author{
Yehia S. Abd El-alkhoris ${ }^{1 *}$, Mohamed S. Abbas ${ }^{2}$, Abbas M. Sharaky² and \\ Mamdouh A. Fahmy ${ }^{3}$ \\ 1- Egyptian Environmental Affairs Agency (EEAA), Egypt. \\ 2- Natural Resources Depart., Faculty of African Postgrad. Studies, Cairo Univ., Egypt. \\ 3- Department of Marine Environment, National Institute of Oceanography and \\ Fisheries, Egypt. \\ * Corresponding Author: yehiasaid@ hotmail.com
}

\section{ARTICLE INFO \\ Article History:}

Received: May 29, 2019

Accepted: Dec. 28, 2019

Online: Jan. 2020

Keywords:

Lake Maruit

Heavy metals

Sediment

Pollution

Environment

\section{ABSTRACT}

The Egyptian Mediterranean Coast has five lakes; all of them, except Lake Maruit, are directly connected to the Sea. The objective of the present study in 2016 is assessing the environmental statement of Lake Maruit (water and sediment quality). The sample from 10 monitoring points distributed along the lake in addition to 3 samples from the main drains and for water samples (temperature, salinity, $\mathrm{pH}$, BOD, DO, COD, eutrophication parameters (ammonia, TSM, nitrate, nitrite, reactive phosphate, silicate, TP and $\mathrm{TN}$ ), heavy metals and microbiological parameters in addition to Total pesticides, PCBs and PHC) while for sediment samples (Sediment Types, Organic Carbon, Organic Matter Content, Water Content, TN, TP, heavy metals and Total pesticides, PCBs and $\mathrm{PHC}$ ) were analyzed. The results revealed that water temperature of the Lake Basins showed variations and ranged from $\left(12.8-31.5^{\circ} \mathrm{C}\right)$ while the annual average concentration of Drains $22.5{ }^{\circ} \mathrm{C}$, Salinity of the Lake ranged between (1.84 - 6.45 Ppt), while the annual average concentration of Drains $1.69 \mathrm{Ppt}$, the distribution pattern of seasonal variations of $\mathrm{pH}$ values was ranged between (7.24 - 9.04), while the annual average concentration of Drains 7.923, Distribution of DO showed a considerable wide range between $(0.00-15.84 \mathrm{mg} / \mathrm{l})$, while the annual average concentration of Drains $4.54 \mathrm{mg} / \mathrm{l}$, BOD in the Lake was ranged between (9.54 - 224.25 $\mathrm{mg} / \mathrm{l}$ ), while the annual average concentration of Drains $76.15 \mathrm{mg} / \mathrm{l}$. Lake Maruit was considered a major source of pollution to the Mediterranean Sea through El-Mex Bay because it receives a huge amount of polluted water from three major sources. On the other hand, the lake water at present has no metal pollution problem. The main pollution problem is due to the oxygen-consuming wastes and the plant nutrients, which had led to depletion in DO.

\section{INTRODUCTION}

The Egyptian Mediterranean Coast exhibits five Lakes or Lagoons which along the Nile Delta Coast (Northern Delta Lakes) and to the East of Suez Canal, These lakes are mainly from West to east: Maruit, Edku, Burullus, Manzallah and Bardaweel, All of them with the exception of Lake Maruit are directly connected to Mediterranean Sea (EEAA, 2011), as shown in map (1). 
But unfortunately many challenges are facing of these takes; degradation \& decreasing the lakes area; spreading of aquatic plant to which reduce the water exchange through the lakes; pollution problems which caused due to the expansion of agricultural, municipal, Industrial and Fish farming activities, These conditions lead to the deterious effects as harm the living organism's \& hazard to the aquatic habitats and change of aquatic biota causing less diverse system (EEAA, 2011).

The increase in population and consequently in man's activities, especially after Aswan High Dam construction constitutes the main cause of pollution in the Nile Delta lakes, mainly eutrophication, as well as the occurrence of heavy metals and pesticide contaminants constituted in these lakes' problems of increasing concern. Lake Manzala occupies the second polluted level after Mariut Lake (Saad, 2003).

The discharge of untreated wastewaters into the four coastal lagoons are causes an ecological degradation and environment deterioration. For example, sewerage output has extended to Mariut lagoon from Alexandria on the northwestern Nile coast, where heavy metals are significantly enriched in the water and sediments. Nowadays, Mariut and Manzala lagoons are the most polluted and Idku and Burullus follow behind. Presently these two lakes are facing critical environmental pressures from local industries and urbanization with the increasing pollutants being expelled towards the lake coast (Kamal and Magdy, 2005).

Lake Maruit is one of four shallow lakes in the northern Nile Delta, it is the smallest and most polluted of these Lakes, and it is the only one that does not currently have a natural connection to the Mediterranean Sea. It is situated southeast of the city of Alexandria (EEAA, 2011). In the last three decades, Lake Maruit has suffered from intensive pollution (El-Shorbagi, 2015), and become rich by nutrients, and has been rated as one of the most productive lakes in the world (Amr et al., 2005), so that Lake Maruit is considered as a highly eutrophic lake which sustains a rich flora of phytoplankton (Samir and Ibrahim, 2008), Over the past decades, Mariut Lake suffers from almost all possible environmental problems to an extreme degree. Anthropogenic pollutants introduced huge amounts of inorganic and organic toxic substances, different forms of nitrogen, phosphorus, heavy metals, pesticides, and pathogens (Mohammed and Ruslan, 2013).

Mariut Lake becomes one of the most polluted lagoons in Egypt due to the urban expansion from the densely populated Alexandria and the uncontrolled deposition of solid wastes, complete very complicated and distressing environmental panorama (Mohamed et al., 2017).

The primary purpose of the study to assess the environmental statement of Lake Maruit, Through the implementation of a semi-integrated program for monitoring water \& sediment of the lake and its drains, in addition, to assess the relationship between pollute. This monitoring program will be very usual for supporting the policy and management decisions of the lake.

\section{MATERIALS AND METHODS}

\section{Study Area}

Lake Mariut is one of the northern Egyptian lakes, located in the north-western coast of Egypt between $31^{\circ} 01^{\prime} 48^{\prime \prime}$ and $31^{\circ} 10^{\prime} 30^{\prime \prime}$ North and $29^{\circ} 49^{\prime} 48^{\prime \prime}$ and $29^{\circ} 57^{\prime}$ $00^{\prime \prime}$ East. The lake extends for about $80 \mathrm{~km}$ along the North West coast of Alexandria and $30 \mathrm{~km}$ south, Mariut Lake is a closed lake, not connected directly with the sea (NIOF, 2008), while its water is pumped to the Mediterranean Sea through El-Max pumping station (EEAA, 2011). 
The total surface area of the Lake (aquatic plants and open water) is 62.89 million $\mathrm{m} 2(63.46 \mathrm{~km} 2)$. The area covered with aquatic plants represents of 60.08 $63.10 \%$ (EEAA, 2011). The main water source discharges into the lake are ElUmoum Drain, El-Qalaa Drain and El-Nubaria Canal (NIOF, 2008). Maruit Lake is bordered by fish farms, villages and agricultural lands and now divided artificially into four main basins, these ponds dissected by highways, railroads, and embankments; namely (EEAA, 2011):

The (Fisheries) Aquaculture Basin (1000 Feddans Basin), is bordered by fish farms in the north, and agricultural lands in the east. It consists of a series of small basins separated by earthen berms, it was covering an area of $9.44 \mathrm{~km} 2$ (849 Feddans), with aquatic plants cover of $11.1 \%$, with average depth $1.8 \mathrm{~m}$, the sources of water discharge into this basin is El-Umoum Drain. (EEAA, 2011).

Main Basin (6000 Feddan1 Basin), The Main Basin is about $14.77 \mathrm{~km}^{2}$ with an average depth of $0.8 \mathrm{~m}$. This basin is heavily polluted by industrial wastes from El El-Qalaa Drain and untreated sewage from municipal and industrial outfalls. Two other sources of water discharge into this basin are the El- Nubaria Canal and West Wastewater Treatment Plant effluent. This basin bordered from north by International Road and form south by Cairo- Alexandria Road. It is surrounded by many industrial companies and extensive human activities from the Kabary region (EEAA, 2011).

Western Basin (3000 Feddans Basin), is about $20.8 \mathrm{~km}^{2}$ with average water depths of $0.7 \mathrm{~m}$, the aquatic plant's area represents of $44.8 \%$ from the total area of the Basin. This Basin is bordered by many industrial and petrochemical companies in the west. Western Basin received its water through El-Nubaria Canal and El-Max pumping station is located also north of the Basin. (EEAA, 2011).

Southern Basin (5000 Feddans basin), is bordered by agricultural lands in the east, and Petroleum Companies and human settlements at the west. The southern Basin covers $24.4 \mathrm{~km}^{2}$ with average depth $0.68 \mathrm{~m}$, The basin is partially divided by EL-Nubaria Canal, the main source of water is El-Umoum Drain at the northern region and EL-Nubaria Canal at the middle region, in addition to many petrochemical and petroleum companies such Amria and Misr Petroleum companies discharge their waste into the north part of this basin. The basin is heavy aquatic plants $(80.4 \%)$ (EEAA, 2011).

\section{Study Period}

The study will be carried out in 2016, the water samples were collected during months of February, May, August, and November. Moreover, the sediment samples were collected during February and August.

\section{Sampling Sites:}

In the study it was selected ten stations for water \& sediment samples to represent different basins in Lake Maruit, and three samples from the drains outfalls (El-Qalaa, El-Umoum drains and EL-Nubaria Canal), in addition, it was recorded for each station its coordinates by using GPS device for easy access, as well each station was given a name and shortcode as showed in Table 1 and Figure 1. 
Table 1: The study Stations and coordinates

\begin{tabular}{|c|c|c|c|c|}
\hline Basin Name & Station Name & Station Code & Latitude & Longitude \\
\hline \multirow{2}{*}{ Fish Basin } & Shader el-samk & FB1 & $31^{\circ} 09^{\prime} 12.6^{\prime \prime}$ & $29^{\circ} 55^{\prime} 37.9^{\prime \prime}$ \\
\hline & El-habsat & FB2 & $31^{\circ} 07^{\prime} 37.6^{\prime \prime}$ & $29^{\circ} 54^{\prime} 1.8^{\prime \prime}$ \\
\hline \multirow{4}{*}{ Main Basin } & Front of Qalaa drain & MB3 & $31^{\circ} 09^{\prime} 35.3^{\prime \prime}$ & $29^{\circ} 55^{\prime} 20.64^{\prime \prime}$ \\
\hline & Northeast of the Abu al-Khair Bridge & MB4 & $31^{\circ} 07^{\prime} 58.1^{\prime \prime}$ & $29^{\circ} 53^{\prime} 35.52^{\prime \prime}$ \\
\hline & Middle of 3000 basin & MB5 & $31^{\circ} 08^{\prime} 48.5^{\prime \prime}$ & $29^{\circ} 53^{\prime} 3.12^{\prime \prime}$ \\
\hline & Front of el-max pump stations & MB 6 & $31^{\circ} 07^{\prime} 29.3^{\prime \prime}$ & $29^{\circ} 52^{\prime} 45.12^{\prime \prime}$ \\
\hline \multirow{2}{*}{ Western (Southwest) Basin } & Start of 5000 basin & SWB7 & $31^{\circ} 07^{\prime} 44.8^{\prime \prime}$ & $29^{\circ} 51^{\prime} 34.56^{\prime \prime}$ \\
\hline & End of 5000 basin & SWB8 & $31^{\circ} 06^{\prime} 25.9^{\prime \prime}$ & $29^{\circ} 55^{\prime} 6.6^{\prime \prime}$ \\
\hline \multirow{2}{*}{ Southern (Northwest) Basin } & Front of western purification station & NWB 9 & $31^{\circ} 06^{\prime} 25.9^{\prime \prime}$ & $29^{\circ} 53^{\prime} 57.84^{\prime \prime}$ \\
\hline & Middle of 2000 basin & NWB10 & $31^{\circ} 04^{\prime} 24.6^{\prime \prime}$ & $29^{\circ} 52^{\prime} 20.28^{\prime}$ \\
\hline
\end{tabular}

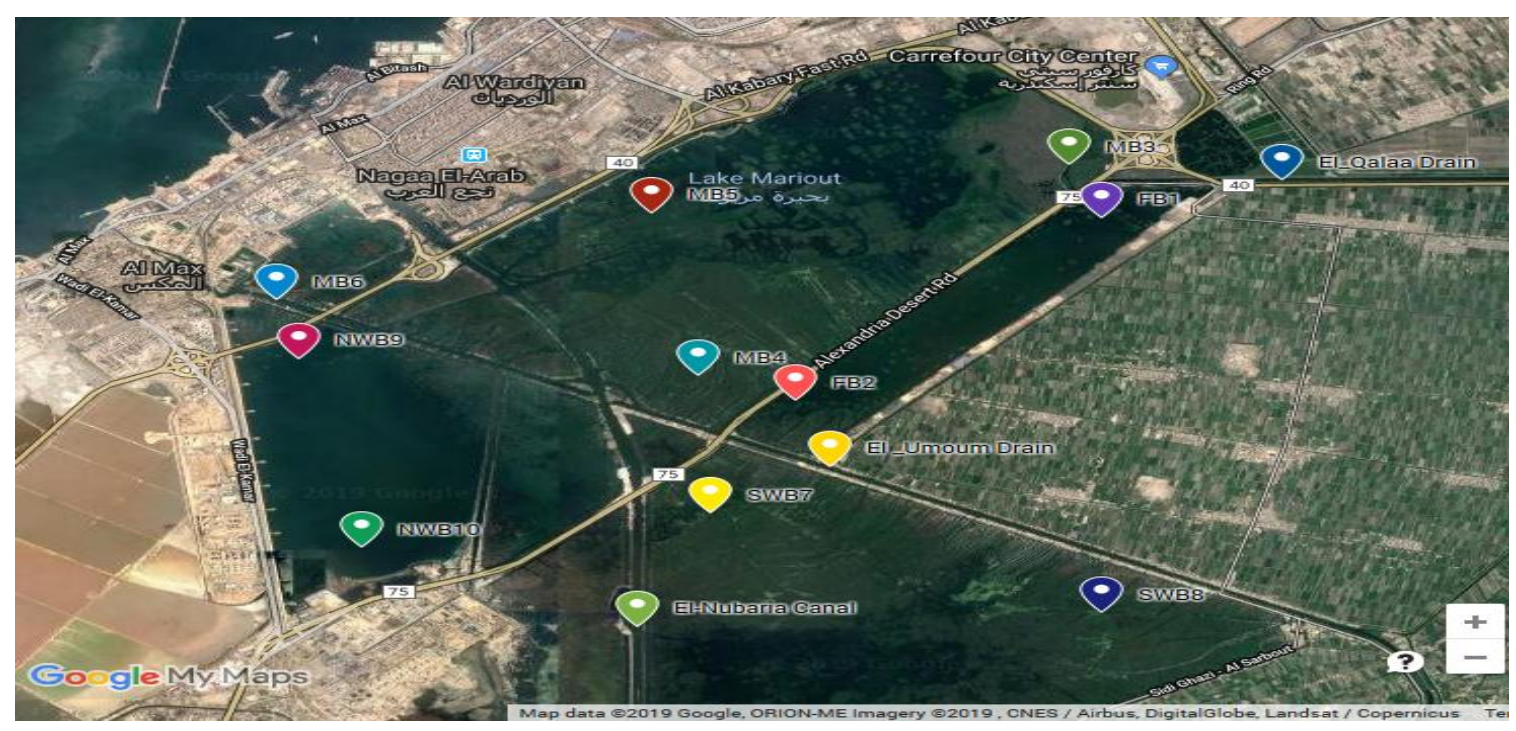

Fig. 1: Map of sampling stations using google earth

\section{Study Sampling:}

Water samples ten surface water samples were collected to represent different basins in Lake Maruit and three samples from the drains outfalls (El-Qalaa, El-Umoum drains and EL-Nubaria Canal), The water samples were kept in Suitable bottles according to the type of analyses, transported to the laboratory, and stored at $-20^{\circ} \mathrm{C}$ until analysis (APHA, 1995).

Sediment samples ten Sediment samples were collected from the same area where the water lake samples were collected, and three samples from the drain's outfalls from the same location where the water drain samples were collected, using VanVeen grab sampler. The sediment samples were kept in polyethylene bottles, transported to the laboratory, and stored at $-20^{\circ} \mathrm{C}$ until analysis (APHA, 1995).

\section{The Data Analysis}

\section{Part One: Water Samples:}

\section{Physical parameters:}

Temperature: Water temperature was measured immediately at the sampling stations using graduated thermometer according to (APHA, 1995).

Salinity: water salinity was measured immediately at the sampling stations using Hydrolab model according to (APHA, 1995).

Transparency: was measured by Secchi disc, according to (Welch, 1952).

Electronic conductivity: water conductivity was measured immediately at the sampling stations using Hydrolab model according to (APHA, 1995). 


\section{Chemical parameters:}

Hydrogen ion (pH): The $\mathrm{pH}$ of water samples was measured by using Hydro-lab model according to (APHA, 1995).

Dissolved oxygen (DO): was measured according to (APHA, 1995).

Biological Oxygen Demand (BOD): was measured according to (APHA, 1995).

Chemical Oxygen Demand (COD): was measured according to (APHA, 1995).

Total suspended matter (TSM): was measured according to (APHA, 1995).

Nutrient salts:

Ammonium ( $\left.\mathbf{N H}_{\mathbf{4}}-\mathbf{N}\right)$ : was measured according to (IOC, 1983).

Nitrite ( $\left.\mathbf{N O}_{2}-\mathbf{N}\right)$ : was measured according to (Grasshoff et al., 1999).

Nitrate $\left(\mathbf{N O}_{3}-\mathbf{N}\right)$ : was measured according to (Grasshoff et al., 1999).

Total nitrogen (TN): was measured according to (Valderrama, 1981).

Reactive phosphate: was measured according to (Grasshoff et al., 1999).

Total phosphorus (TP): was measured according to (Valderrama, 1981).

Reactive silicate ( $\left.\mathbf{S i O}_{4}-\mathbf{S i}\right)$ : was measured according to (Koroleff, 1971).

Heavy Metals: was measured according to (Riley and Taylor, 1968).

Chlorophyll-a (Chl-A): Chl-A of water samples was measured according to (Strickland and Parsons, 1972).

Microbiology: The bacteriological sampling technique was done according to (the international standard ISO 5667/1 and ISO 5667/2, 1992).

Pesticides and Poly-chlorinated biphenyls $\left(\mathbf{P C B}_{\mathbf{S}}\right)$ : $1000 \mathrm{ml}$ of Lake Water samples were measured according to (APHA, 1995).

Determination of petroleum hydrocarbons using UV Spectrofluorometer: Lake Water samples according to (Parsons et al., 1985; UNEP/IOC/IAEA, 1992).

Part Two Sediments Samples

Determination of Organic Matter: was measured according to (APHA, 1995).

Determination of water content was measured according to (APHA, 1995).

Total nitrogen (TN): was measured according to (APHA, 1995).

Total phosphorus (TP): was measured according to (APHA, 1995).

Heavy Metals: Heavy metals in surficial sediment samples ( $\mathrm{Fe}, \mathrm{Mn}, \mathrm{Cd}, \mathrm{Cu}, \mathrm{Pb}, \mathrm{Cr}$, $\mathrm{Zn}$, and $\mathrm{Ni}$ ) were measured according to (Oregioni and Aston, 1984), While the total mercury was measured according to (Azemared and Coquery, 1997).

Pesticides and Poly-chlorinated biphenyls $\left(\mathbf{P C B}_{\mathrm{S}}\right)$ : $1000 \mathrm{ml}$ of Lake Sediment samples were measured according to (APHA, 1995).

Determination of petroleum hydrocarbons using UV Spectrofluorometer: Lake Sediment samples according to (Parsons et al., 1985).

\section{RESULTS}

\section{Physicochemical Characteristics for Water Samples:}

Water temperature: During the present study, the water temperature of the Lake was ranged between $\left(12.8-31.5{ }^{\circ} \mathrm{C}\right)$ with annual average concentration overall the lake $21.18{ }^{\circ} \mathrm{C}$, while the annual average concentration overall Drains $22.5{ }^{\circ} \mathrm{C}$, as it was clear in Table (2). Although the results show clear variations in temperature during the different months of the year that can be the affected of the number of sunrise hours per day and the time of collection of the sample, the temperature of the lake is suitable for the life and growth of fish most months of the year.

Hydrogen ion concentration (pH): The distribution pattern of seasonal variations of $\mathrm{pH}$ values, it was ranged between the less value $(7.24-8.28)$, with annual average concentration overall the lake 9.04, while the annual average concentration overall 
Drains 7.923, (Table 2). The current study is consistent with previous studies where the study showed that the lake water is located on the alkali side.

Salinity: water salinity of the Lake was ranged between $(1.84-6.45 \mu \mathrm{g} / \mathrm{l})$, with annual average concentration overall the lake $3.93 \mu \mathrm{g} / \mathrm{l}$, while the annual average concentration overall Drains $1.69 \mu \mathrm{g} / \mathrm{l}$, as it shows in Table (2), the results show Clear disparities in the salinity of the lake water between the different stations where salinity is significantly increased in Fisheries Basin, The increase in salinity concentrations in the basin can be explained by the drainage of relatively high concentrations of salts from agriculture and fish farms on this basin.

Conductivity: water Conductivity of the Lake was ranged between the fewer values (3.75- $12.41 \mathrm{mS} / \mathrm{cm}$ ), with annual average concentration overall the lake $6.88 \mathrm{mS} / \mathrm{cm}$, while the annual average concentration overall Drains was $3.11 \mathrm{mS} / \mathrm{cm}$ (Table 2). The distribution of the conductivity values is consistent with the distribution of the salinity of the lake water between the different stations where Conductivity is significantly increased in the Fisheries Basin as the concentrations of salinity.

Dissolved Oxygen (DO): concentrations of dissolved oxygen of the Lake water was ranged between $(0.00-15.84 \mathrm{mg} / \mathrm{l})$, with annual average concentration overall the lake $8.03 \mathrm{mg} / \mathrm{l}$, while the annual average concentration overall Drains $4.54 \mathrm{mg} / \mathrm{l}$, as it was seen in Table (2), the current study is consistent with the previous studies. Which indicate that the concentration of dissolved oxygen in the different stations in the lake is affected by the proximity of the stations from sources of pollution (Drains) where it completely disappear in front of El-Qalaa Drain, This can be explained as a result of the large amounts of organic matter in El-Qalaa Drain resulting from sewage treatment plants. As a result of the activity of bacteria that feed on organic matter and consume dissolved oxygen in the water, there is no concentration of dissolved oxygen and this will lead to destruction and death of all living organisms.

Biological Oxygen Demand (BOD): concentration of organic materials represented by the biological oxygen demand (BOD) of the Lake water was ranged between $(9.54$ - $224.25 \mathrm{mg} / \mathrm{l}$ ), with annual average concentration overall the lake $65.78 \mathrm{mg} / \mathrm{l}$, while the annual average concentration overall Drains $76.15 \mathrm{mg} / \mathrm{l}$, Table (2), the study showed the differences in the values of BOD from the different stations during the study period due to the increase of organic pollutants from El-Qalaa Drain which carry huge amounts of organic matter which Leads to Increase bacterial activity in this area.

Chemical Oxygen Demand (COD):concentration of organic materials represented by the Chemical Oxygen Demand (COD) of the Lake water was ranged between $(18.93$ - $409.76 \mathrm{mg} / \mathrm{l})$, with annual average concentration overall the lake 105.66 $\mathrm{mg} / \mathrm{l}$, while the annual average concentration overall Drains $230.212 \mathrm{mg} / \mathrm{l}$, as shown in Table (2), the results showed that the main basin of Lake Maruit contains the highest value of the oxygen consumed not only between the basins of Lake Maruit but also among all the Northern lakes due to the influence of El-Qalaa Drain, which is loaded with different types of pollutants.

Chlorophyll (Chl-a): Chlorophyll-A of the Lake water was ranged between $(0.1$ $217.805 \mu \mathrm{g} / \mathrm{l})$ with annual average concentration overall the lake $33.85 \mu \mathrm{g} / \mathrm{l}$, while annual average concentration overall Drains $14.0489 \mu \mathrm{g} / \mathrm{l}$, as it was shown in Table (2), the results of the analysis confirmed that the value of chlorophyll-a was generally low in front and in El-Qalaa Drain, which is poor in chlorophyll-a, because of the lack of oxygen which leads to the death of any living organism.

Total Suspended Matter (TSM): Total Suspended Matter (TSM) of the Lake water was ranged between $(18.1$ - $152.9 \mathrm{mg} / \mathrm{l})$, with annual average concentration overall 
the lake $64.075 \mathrm{mg} / \mathrm{l}$, while the annual average concentration overall Drains 43.54 $\mathrm{mg} / \mathrm{l}$, (Table 2).

Table 2: Shows average concentrations of physicochemical characteristics for Water Lake

\begin{tabular}{|c|c|c|c|c|c|c|c|c|c|c|}
\hline \multirow[t]{2}{*}{ Regions } & \multirow[t]{2}{*}{ Stations } & \multirow{2}{*}{$\begin{array}{c}\text { Temperature } \\
\left({ }^{\circ} \mathrm{C}\right)\end{array}$} & \multirow{2}{*}{$\begin{array}{c}\text { Conductivity } \\
\mathrm{mS} / \mathrm{cm}\end{array}$} & \multirow{2}{*}{$\begin{array}{c}\text { Salinity } \\
\mu \mathrm{g} / 1\end{array}$} & \multirow[t]{2}{*}{$\mathrm{pH}$} & \multirow{2}{*}{\multicolumn{4}{|c|}{$\mathrm{mg} / \mathrm{l}$}} & \multirow{2}{*}{$\begin{array}{l}\text { Chl-a } \\
\mu \mathrm{g} / \mathrm{l}\end{array}$} \\
\hline & & & & & & & & & & \\
\hline \multirow[t]{2}{*}{ FB } & FB 1 & 21.588 & 9.373 & 5.348 & 8.25 & 9.26875 & 55.918 & 98.555 & 78.138 & 5.448 \\
\hline & FB 2 & 22.325 & 8.615 & 4.9425 & 8.425 & 10.63125 & 44.3825 & 77.96 & 69.963 & 14.173 \\
\hline \multirow[t]{4}{*}{ MB } & MB 3 & 22.25 & 3.955 & 2.213 & 7.658 & 0.00 & 109.093 & 169.708 & 84.013 & 14.968 \\
\hline & MB 4 & 20.575 & 4.97 & 2.7825 & 7.8425 & 5.2225 & 56.965 & 78.185 & 55.475 & 34.24 \\
\hline & MB 5 & 20.45 & 4.9975 & 2.7875 & 8.2125 & 9.59 & 66.2725 & 99.0375 & 60.313 & 115.9575 \\
\hline & MB 6 & 21 & 6.75 & 3.8875 & 7.735 & 0.875 & 76.8475 & 156.2625 & 69.438 & 30.555 \\
\hline \multirow[t]{2}{*}{ SB } & SWB 7 & 20.7 & 9.295 & 5.2975 & 8.11 & 8.52125 & 68.35 & 101.765 & 58.313 & 29.2175 \\
\hline & SWB 8 & 21.375 & 5.2875 & 3 & 7.915 & 7.09625 & 70.1325 & 118.92 & 73.8 & 35.9275 \\
\hline \multirow[t]{2}{*}{ NB } & NWB 9 & 20.675 & 7.7475 & 4.5125 & 8.1475 & 8.6225 & 54.5225 & 80.3675 & 56.3 & 52.365 \\
\hline & NWB 10 & 20.875 & 7.8825 & 4.605 & 8.035 & 13.895 & 55.4 & 75.9125 & 35 & 5.725 \\
\hline \multicolumn{11}{|c|}{ Drains } \\
\hline \multicolumn{2}{|c|}{ El-Qalaa Drain } & 23.2 & 3.74 & 2.03 & 7.59 & 0.00 & 115.13 & 447.15 & 58.01 & 6.84 \\
\hline \multirow{2}{*}{\multicolumn{2}{|c|}{$\begin{array}{l}\text { EL-Nubaria Canal } \\
\text { El-Umoum Drain }\end{array}$}} & 22.8 & 0.71 & 0.30 & 8.38 & 9.48 & 50.14 & 103.95 & 28.86 & 12.38 \\
\hline & & 21.5 & 4.87 & 2.69 & 7.80 & 4.16 & 63.177 & 139.54 & 43.75 & 22.93 \\
\hline
\end{tabular}

\section{Nutrient Salts for Water Samples}

Ammonia $\left(\mathbf{N H}_{4}-\mathbf{N}\right)$ : ammonium concentration of the Lake water was ranged between $(0.01736-15.19 \mathrm{mg} / \mathrm{l})$, with annual average concentration overall the lake $1.78 \mathrm{mg} / \mathrm{l}$, while the annual average concentration overall Drains $5.111 \mathrm{mg} / \mathrm{l}$, as it was clear from Table (3), The results confirmed that high values of Ammonia were recorded at the front and in El-Qalaa Drain.

Nitrites $\left(\mathbf{N O}_{2}-\mathbf{N}\right)$ : Nitrites concentration values of the Lake water was ranged between $(0.00-561.658 \mu \mathrm{g} / \mathrm{l})$ with annual average concentration overall the lake $122.98 \mu \mathrm{g} / \mathrm{l}$, and with annual average concentration overall Drains $122.627 \mu \mathrm{g} / \mathrm{l}$, as it was shown in Table (3), the low concentration values were recorded at the front and in El-Qalaa Drain, The decrease of $\mathrm{NO}_{2}-\mathrm{N}$ contents might be attributed to the increase in the oxidation rate of nitrite to nitrate.

Nitrate $\left(\mathrm{NO}_{3}-\mathbf{N}\right)$ : Nitrate concentration of the Lake water was ranged between $(0.008$ - $2.245 \mathrm{mg} / \mathrm{l}$ ) with annual average concentration overall the lake $0.427 \mathrm{mg} / \mathrm{l}$, while annual average concentration overall Drains $0.383 \mathrm{mg} / \mathrm{l}$, (Table 3 ).

Total Nitrogen (TN): Total Nitrogen concentration of the Lake water was ranged between $(1.91-27.52 \mathrm{mg} / \mathrm{l})$ with annual average concentration overall the lake 8.35 $\mathrm{mg} / \mathrm{l}$, while annual average concentration overall Drains $15.0567 \mathrm{mg} / \mathrm{l}$, as seen in Table (3).

Dissolved Inorganic Phosphorus (DIP): Dissolved inorganic Phosphorus concentration of the Lake water was ranged between $(7.6-3009.44 \mu \mathrm{g} / \mathrm{l})$ with annual average concentration overall the lake $321.75 \mu \mathrm{g} / \mathrm{l}$, while annual average concentration overall Drains $686.29 \mu \mathrm{g} / 1$, as shown in Table (3).

Total phosphorus (TP): Total phosphorous concentration of the Lake water was ranged between $(43.66-3374.69 \mu \mathrm{g} / \mathrm{l})$ with annual average concentration overall the lake $601.60 \mu \mathrm{g} / \mathrm{l}$, while annual average concentration overall Drains $1108.38 \mu \mathrm{g} / \mathrm{l}$, as shown in Table (3).

Reactive Silicate $\left(\mathrm{SiO}_{4}-\mathrm{Si}\right)$ : Reactive Silicate concentration of the Lake water was ranged between $(1.08-19.55 \mathrm{mg} / \mathrm{l})$ with annual average concentration overall the lake $7.876 \mathrm{mg} / \mathrm{l}$, while annual average concentration overall Drains $5.775 \mathrm{mg} / \mathrm{l}$ (Table 3). 
Table 3: Shows average concentrations of Nutrient salts characteristics for Water lake

\begin{tabular}{|c|c|c|c|c|c|c|c|c|}
\hline \multirow[t]{2}{*}{ Regions } & \multirow[t]{2}{*}{ Stations } & $\mathrm{NH}_{4}$ & $\mathrm{NO}_{2}$ & $\mathrm{NO}_{3}$ & $T N$ & $\mathrm{PO}_{4}$ & $T P$ & $\mathrm{SiO}_{4}$ \\
\hline & & $\mathrm{mg} / \mathrm{l}$ & $\mu \mathrm{g} / \mathrm{l}$ & \multicolumn{2}{|c|}{$\mathrm{mg} / \mathrm{l}$} & \multicolumn{2}{|c|}{$\mu \mathrm{g} / 1$} & $\mathrm{mg} / \mathrm{l}$ \\
\hline \multirow[t]{2}{*}{ FB } & FB 1 & 0.079 & 12.565 & 0.042 & 3.665 & 14.265 & 73.37 & 10.338 \\
\hline & FB 2 & 0.047 & 9.698 & 0.068 & 4.268 & 342.833 & 93.29 & 11.735 \\
\hline \multirow[t]{4}{*}{$\mathrm{MB}$} & MB 3 & 11.1 & 7.803 & 0.031 & 25.22 & 1481.7 & 2659.54 & 5.593 \\
\hline & MB 4 & 1.18025 & 364.085 & 1.20775 & 10.175 & 297.28 & 584.65 & 9.685 \\
\hline & MB 5 & 0.23 & 147.82 & 0.31775 & 6.695 & 247.1625 & 565.81 & 4.2175 \\
\hline & MB 6 & 3.80425 & 134.235 & 0.57525 & 11.6825 & 443.63 & 1017.79 & 7.8675 \\
\hline \multirow[t]{2}{*}{ SB } & SWB 7 & 0.40325 & 69.0575 & 0.345 & 5.09 & 37.0125 & 152.79 & 5.2275 \\
\hline & SWB 8 & 0.586 & 304.8575 & 0.91875 & 7.335 & 248.3875 & 496.82 & 8.875 \\
\hline \multirow[t]{2}{*}{ NB } & NWB 9 & 0.329 & 144.38 & 0.51375 & 5.7175 & 53.15 & 257.69 & 6.61 \\
\hline & NWB 10 & 0.1025 & 35.365 & 0.25375 & 3.6775 & 52.0825 & 114.23 & 7.82 \\
\hline \multicolumn{9}{|c|}{ Drains } \\
\hline \multicolumn{2}{|c|}{ El-Qalaa Drain } & 12.31 & 16.80 & 0.04 & 25.98 & 1663.32 & 3225 & 5.92 \\
\hline \multicolumn{2}{|c|}{ EL-Nubaria Canal } & 0.60 & 38.50 & 0.18 & 8.54 & 43.15 & 27475 & 1.33 \\
\hline \multicolumn{2}{|c|}{ El-Umoum Drain } & 2.42 & 312.58 & 0.93 & 10.66 & 352.38 & 21175 & 10.08 \\
\hline
\end{tabular}

Heavy Metals for Water samples:

Dissolved Iron (D-Fe): Dissolved iron concentrations of the Lake water was ranged between $(10.73-275.24 \mu \mathrm{g} / \mathrm{l})$, with annual average concentration overall the lake $86.65 \mu \mathrm{g} / \mathrm{l}$, while the annual average concentration overall Drains $57.6486 \mu \mathrm{g} / \mathrm{l}$, (Table 4).

Dissolved Manganese (D-Mn): Dissolved Manganese concentrations of the Lake water was ranged between $(1.0744-117.38 \mu \mathrm{g} / \mathrm{l})$, with annual average concentration overall the lake $33.9805 \mu \mathrm{g} / \mathrm{l}$, while the annual average concentration overall Drains $27.285 \mu \mathrm{g} / \mathrm{l}$, (Table 4).

Dissolved Copper (D-Cu): Dissolved Copper concentrations of the Lake water was ranged between $(0.3175-8.55 \mu \mathrm{g} / \mathrm{l})$, with annual average concentration overall the lake $2.415 \mu \mathrm{g} / 1$, while the annual average concentration overall Drains $3.364 \mu \mathrm{g} / \mathrm{l}$, (Table 4).

Dissolved Zinc (D-Zn): Dissolved Zinc concentrations of the Lake water was ranged between $(2.289-61.532 \mu \mathrm{g} / \mathrm{l})$, with annual average concentration overall the lake $13.156 \mu \mathrm{g} / \mathrm{l}$, while the annual average concentration overall Drains $10.4967 \mu \mathrm{g} / \mathrm{l}$, (Table 4).

Dissolved Chromium (D-Cr): Dissolved Chromium concentrations of the Lake water was ranged between $(0.00-10.445 \mu \mathrm{g} / \mathrm{l})$, with annual average concentration overall the lake $5.422 \mu \mathrm{g} / \mathrm{l}$, while the annual average concentration overall Drains $5.6309 \mu \mathrm{g} / 1$, (Table 4).

Dissolved Nickel (D-Ni): Dissolved Nickel concentrations of the Lake water was ranged between $(1.56-96.607 \mu \mathrm{g} / \mathrm{l})$, with annual average concentration overall the lake $14.655 \mu \mathrm{g} / \mathrm{l}$, while the annual average concentration overall Drains $11.979 \mu \mathrm{g} / \mathrm{l}$, (Table 4).

Dissolved Cadmium (D-Cd): Dissolved Cadmium concentrations of the Lake water was ranged between $(0.00-2.862 \mu \mathrm{g} / \mathrm{l})$, with annual average concentration overall the lake $0.7562 \mu \mathrm{g} / \mathrm{l}$, while the annual average concentration overall Drains $0.4037 \mu \mathrm{g} / \mathrm{l}$, (Table 4).

Dissolved Lead (D-Pb): Dissolved lead concentrations of the Lake water was ranged between $(0.830-18.637 \mu \mathrm{g} / \mathrm{l})$, with annual average concentration overall the lake $5.988 \mu \mathrm{g} / \mathrm{l}$, while the annual average concentration overall Drains $6.553 \mu \mathrm{g} / \mathrm{l}$, (Table 4).

Dissolved Mercury (D-Hg): Dissolved Mercury concentrations of the Lake water was ranged between $(0.00-0.064 \mu \mathrm{g} / \mathrm{l})$, with annual average concentration overall the 
lake $0.0170 \mu \mathrm{g} / \mathrm{l}$, while the annual average concentration overall Drains $0.016 \mu \mathrm{g} / \mathrm{l}$, (Table 4).

Table 4: Shows average concentrations of Heavy Metals characteristics for Water lake

\begin{tabular}{|c|c|c|c|c|c|c|c|c|c|c|}
\hline \multirow[t]{2}{*}{ Regions } & \multirow[t]{2}{*}{ Stations } & $\mathrm{Fe}$ & $\mathrm{Mn}$ & $\mathrm{Cu}$ & $\mathrm{Zn}$ & $\mathrm{Cr}$ & $\mathrm{Ni}$ & $\mathrm{Cd}$ & $\mathrm{Pb}$ & $\mathrm{Hg}$ \\
\hline & & \multicolumn{9}{|c|}{$\mu \mathrm{g} / 1$} \\
\hline \multirow[t]{2}{*}{ FB } & FB 1 & 91.04 & 26.56 & 3.09 & 13.11 & 4.92 & 48.99 & 1.09 & 6.08 & 0.069 \\
\hline & FB 2 & 71.02 & 10.66 & 2.16 & 9.97 & 3.44 & 19.54 & 1.04 & 6.28 & 0.037 \\
\hline \multirow[t]{4}{*}{ MB } & MB 3 & 101.35 & 107.51 & 1.54 & 7.75 & 5.74 & 10.87 & 0.75 & 6.83 & 0.034 \\
\hline & MB 4 & 84.36 & 31.34 & 4.77 & 12.99 & 6.62 & 13.74 & 0.73 & 6.70 & 0.032 \\
\hline & MB 5 & 83.91 & 27.33 & 2.06 & 9.38 & 5.57 & 8.74 & 0.95 & 8.15 & 0.021 \\
\hline & MB 6 & 137.51 & 64.60 & 1.79 & 14.90 & 3.83 & 9.23 & 0.89 & 5.78 & 0.016 \\
\hline \multirow[t]{2}{*}{ SB } & SWB 7 & 59.71 & 20.38 & 1.61 & 13.61 & 6.51 & 6.90 & 0.74 & 6.58 & 0.017 \\
\hline & SWB 8 & 74.93 & 24.86 & 1.90 & 23.25 & 5.42 & 8.90 & 0.57 & 5.93 & 0.026 \\
\hline \multirow[t]{2}{*}{ NB } & NWB 9 & 58.82 & 11.81 & 2.45 & 13.90 & 6.94 & 14.64 & 0.43 & 4.99 & 0.028 \\
\hline & NWB 10 & 102.83 & $\begin{array}{l}14.98 \\
\text { Drains }\end{array}$ & 3.76 & 13.47 & 5.24 & 5.30 & 0.34 & 3.14 & 0.021 \\
\hline \multicolumn{2}{|c|}{ El-Qalaa Drain } & 98.66 & 57.51 & 2.61 & 7.93 & 7.27 & 25.53 & 0.46 & 5.47 & 0.020 \\
\hline \multicolumn{2}{|c|}{ EL-Nubaria Canal } & 42.82 & 9.07 & 4.07 & 12.82 & 5.30 & 5.55 & 0.38 & 5.16 & 0.025 \\
\hline \multicolumn{2}{|c|}{ El-Umoum Drain } & 31.46 & 15.27 & 3.41 & 10.74 & 4.33 & 4.86 & 0.37 & 9.04 & 0.026 \\
\hline
\end{tabular}

Biological Parameter for Water samples:

Total Coliforms (TC) Bacteria: Total coliforms bacteria of the Lake water was ranged between $(6-111000$ cell/100ml), with the annual average overall the lake 11898 cell $/ 100 \mathrm{ml}$, while the annual average overall Drains 57660 cell/100ml, (Table 5).

E. coli (PE.c) Bacteria: E. coli bacteria of the Lake water was ranged between (1 89000 cell $/ 100 \mathrm{ml}$ ), with annual average overall the lake 8504 cell $/ 100 \mathrm{ml}$, while the annual average overall Drains 42042 cell/100ml, (Table 5).

Table 5: Shows average concentrations Biological Parameter for Water lake

\begin{tabular}{|c|c|c|c|c|}
\hline \multirow[t]{2}{*}{ Regions } & \multirow[t]{2}{*}{ Stations } & Total Coliforms (TC) & E. coli (PE.c) & Fecal streptococci (FS) \\
\hline & & \multicolumn{3}{|c|}{ Cell/100ml } \\
\hline \multirow[t]{2}{*}{ FB } & FB 1 & 463 & 368 & 153 \\
\hline & FB 2 & 169 & 94 & 25 \\
\hline \multirow[t]{4}{*}{ MB } & MB 3 & 45750 & 30950 & 16650 \\
\hline & MB 4 & 7413 & 6075 & 1450 \\
\hline & MB 5 & 3115 & 1470 & 644 \\
\hline & MB 6 & 61250 & 45500 & 25400 \\
\hline \multirow[t]{2}{*}{ SB } & SWB 7 & 68 & 50 & 26 \\
\hline & SWB 8 & 564 & 445 & 172 \\
\hline \multirow[t]{2}{*}{ NB } & NWB 9 & 82 & 52 & 20 \\
\hline & NWB 10 & 109 & 50 & 90 \\
\hline \multicolumn{5}{|c|}{ Drains } \\
\hline \multicolumn{2}{|c|}{ El-Qalaa Drain } & 112500 & 79750 & 59500 \\
\hline \multicolumn{2}{|c|}{ EL-Nubaria Canal } & 230 & 125 & 63 \\
\hline \multicolumn{2}{|c|}{ El-Umoum Drain } & 60250 & 46250 & 43000 \\
\hline
\end{tabular}

Fecal streptococci (FS) Bacteria: Faecal streptococci bacteria of the Lake water was ranged between $(1-80000$ cell/100ml), with annual average overall the lake 4458 cell $/ 100 \mathrm{ml}$, while the annual average overall Drains 34188 cell $/ 100 \mathrm{ml}$ (Table 5).

Total pesticides \& polychlorinated biphenyls (PCBs) and Petroleum hydrocarbons for Water samples: 
In general, PCBs concentrations of the Lake water was ranged between (2.283 $22.403 \mathrm{ng} / \mathrm{l}$, with annual average concentration overall the lake $5.028 \mathrm{ng} / \mathrm{l}$, while the annual average concentration overall Drains $5.028 \mathrm{ng} / \mathrm{l}$, (Table 6), while Total pesticides concentrations of the Lake water was ranged between $(0.350-7.016 \mathrm{ng} / \mathrm{l})$, with annual average concentration overall the lake $1.547 \mathrm{ng} / \mathrm{l}$, while the annual average concentration overall Drains $2.697 \mathrm{ng} / \mathrm{l}$, as shown in table No.6., but for Petroleum hydrocarbons concentrations of the Lake water was ranged between $(0.104$ - $1.237 \mu \mathrm{g} / \mathrm{l}$ ), with annual average concentration overall the lake $0.467 \mu \mathrm{g} / \mathrm{l}$, while the annual average concentration overall Drains $0.5798 \mu \mathrm{g} / 1$ (Table 6).

Table 6: Shows average concentrations Total pesticides\& polychlorinated biphenyls (PCBs) and Petroleum hydrocarbons Parameters for Water lake

\begin{tabular}{clccc}
\hline Regions & Stations & PCBs & Total pesticides & Petroleum hydrocarbons $(P H C)$ \\
\cline { 3 - 5 } & & 4.75 & 1.09 & 0.61 \\
FB & FB 1 & 4.13 & 1.16 & 0.45 \\
& FB 2 & 1.18 & 0.72 \\
MB & MB 3 & 4.71 & 1.15 & 0.41 \\
& MB 4 & 4.64 & 1.26 & 0.37 \\
& MB 5 & 4.90 & 1.37 & 0.40 \\
SB & MB 6 & 4.21 & 1.40 & 0.31 \\
NB & 4.13 & 1.92 & 0.53 \\
& SWB 8 & 4.39 & 2.15 & 0.45 \\
& NWB 9 & 5.96 & 2.89 & 0.44 \\
El-Qalaa Drain & 8.70 & Drains & 0.70 \\
EL-Nubaria Canal & 11.72 & 3.23 & 0.46 \\
El-Umoum Drain & 6.95 & 2.75 & 0.58 \\
\hline
\end{tabular}

Physicochemical characteristics for Sediment samples:

Sediment Types Distribution : Percentage of sand sediments of the Lake sediment was ranged between $(0.75-96.68 \%)$, with annual average concentration overall the lake sediments $26.18 \%$, while the annual average concentration overall Drains 29.45 $\%$, But for Percentage of Mud sediments During the present study, Percentage of Mud sediments of the Lake sediment was ranged between $(3.32-99.25 \%)$, with annual average concentration overall the lake sediments $73.82 \%$, while the annual average concentration overall Drains $70.56 \%$, (Table 7).

\section{Organic Carbon and Organic Matter Content}

Percentage of Organic Carbon in the Lake sediment was ranged between (0.34 - $6 \%)$, with annual average concentration overall the lake sediments $3.98 \%$, while the annual average concentration overall Drains $5.13 \%$, but for Organic Content in the Lake sediment was ranged between $(0.61-10.8 \%)$, with annual average concentration overall the lake sediments $7.17 \%$, while the annual average concentration overall Drains $2.85 \%$, (Table 7).

Water Content: Water Content in the Lake sediment was ranged between (19 - 83 $\%$ ), with annual average concentration overall the lake sediments $62.2 \%$, while the annual average concentration overall Drains $51.83 \%$, (Table 7).

Total Nitrogen (TN): Total Nitrogen of the Lake sediment was ranged between $(0.25-0.71 \%)$, with annual average concentration overall the lake $0.458 \%$, while the annual average concentration overall Drains $0.641 \%$, (Table 7).

Total phosphorus (TP): Total phosphorous of the Lake sediment was ranged between $(250.95-1671.97 \mu \mathrm{g} / \mathrm{g})$, with annual average concentration overall the lake 
$1002.641 \mu \mathrm{g} / \mathrm{g}$, while the annual average concentration overall Drains $1315.67 \mu \mathrm{g} / \mathrm{g}$ (Table 7).

Table 7: Shows average concentrations of Physicochemical characteristics for Sediment lake

\begin{tabular}{|c|c|c|c|c|c|c|c|c|}
\hline \multirow[t]{2}{*}{ Regions } & \multirow[t]{2}{*}{ Stations } & sand & Mud & $\begin{array}{l}\text { Water } \\
\text { con. }\end{array}$ & Organiccon. & Carbon con. & TN & \multirow[t]{2}{*}{ TP } \\
\hline & & \multicolumn{6}{|c|}{$\%$} & \\
\hline \multirow[t]{2}{*}{ FB } & FB 1 & 10.78 & 89.23 & 61.50 & 7.03 & 3.91 & 0.39 & 961.5 \\
\hline & FB 2 & 95.89 & 4.12 & 20.50 & 0.89 & 0.50 & 0.47 & 271 \\
\hline \multirow[t]{4}{*}{ MB } & MB 3 & 14.61 & 85.40 & 66.00 & 8.64 & 4.80 & 0.32 & 1354 \\
\hline & MB 4 & 28.54 & 71.47 & 58.00 & 4.80 & 2.67 & 0.45 & 1048.5 \\
\hline & MB 5 & 12.35 & 87.65 & 81.50 & 9.53 & 5.30 & 0.45 & 1555 \\
\hline & MB 6 & 22.18 & 77.82 & 52.00 & 4.12 & 2.29 & 0.51 & 1017.5 \\
\hline \multirow[t]{2}{*}{ SB } & SWB 7 & 21.77 & 78.24 & 73.00 & 8.64 & 4.80 & 0.54 & 1197 \\
\hline & SWB 8 & 12.50 & 87.46 & 72.50 & 10.14 & 5.63 & 0.42 & 949.5 \\
\hline \multirow[t]{2}{*}{ NB } & NWB 9 & 18.58 & 81.43 & 64.50 & 9.01 & 5.01 & 0.49 & 871 \\
\hline & NWB 10 & 24.61 & 75.40 & $\begin{array}{r}72.50 \\
\text { Di }\end{array}$ & 8.88 & 4.93 & 0.56 & 801.5 \\
\hline \multicolumn{2}{|c|}{ El-Qalaa Drain } & 33.21 & 66.79 & 54.50 & 8.56 & 4.76 & 0.72 & 1949.5 \\
\hline \multicolumn{2}{|c|}{ EL-Nubaria Canal } & 41.96 & 58.04 & 42.50 & 1.97 & 1.10 & 0.64 & 1144.5 \\
\hline \multicolumn{2}{|c|}{ El-Umoum Drain } & 13.17 & 86.84 & 58.50 & 4.85 & 2.69 & 0.56 & 1010.5 \\
\hline
\end{tabular}

\section{Heavy Metals for Sediment samples}

Dissolved Iron (D-Fe): Dissolved iron concentrations of the Lake sediment was ranged between $(945-23933 \mu \mathrm{g} / \mathrm{g})$, with annual average concentration overall the lake $9154.25 \mu \mathrm{g} / \mathrm{g}$, while the annual average concentration overall Drains 11504.67 $\mu \mathrm{g} / \mathrm{g}$ (Table 8).

Dissolved Manganese (D-Mn): Dissolved Manganese concentrations of the Lake Sediment was ranged between $(106-661 \mu \mathrm{g} / \mathrm{g})$, with annual average concentration overall the lake Sediment $362.502 \mu \mathrm{g} / \mathrm{g}$, while the annual average concentration overall Drains $414.5 \mu \mathrm{g} / \mathrm{g}$ (Table 8 ).

Dissolved Copper (D-Cu): Dissolved Copper concentrations of the Lake Sediment was ranged between $(1.8-167.57 \mu \mathrm{g} / \mathrm{g})$, with annual average concentration overall the lake Sediment $36.135 \mu \mathrm{g} / \mathrm{g}$, while the annual average concentration overall Drains $307.1 \mu \mathrm{g} / \mathrm{g}($ Table 8$)$.

Dissolved Zinc (D-Zn): Dissolved Zinc concentrations of the Lake Sediment was ranged between $(33.49-270.95 \mu \mathrm{g} / \mathrm{g})$, with annual average concentration overall the lake $80.252 \mu \mathrm{g} / \mathrm{g}$, while the annual average concentration overall Drains $103.548 \mu \mathrm{g} / \mathrm{g}$ (Table 8).

Dissolved Chromium (D-Cr): Dissolved Chromium concentrations of the Lake Sediment was ranged between $(8.75-109.9 \mu \mathrm{g} / \mathrm{g})$, with annual average concentration overall the lake Sediment $47.97 \mu \mathrm{g} / \mathrm{g}$, while the, with annual average concentration overall, Drains Sediment $60.25 \mu \mathrm{g} / \mathrm{g}$, as shown in table No.8.

Dissolved Nickel (D-Ni): Dissolved Nickel concentrations of the Lake Sediment was ranged between $(8.02-62.43 \mu \mathrm{g} / \mathrm{g})$, with annual average concentration overall the lake Sediment $23.946 \mu \mathrm{g} / \mathrm{g}$, while the annual average concentration overall Drains Sediment 38.911 $\mathrm{g} / \mathrm{g}$ (Table 8).

Dissolved Cadmium (D-Cd): Dissolved Cadmium concentrations of the Lake Sediment was ranged between $(0.00-0.915 \mu \mathrm{g} / \mathrm{g})$, with annual average concentration overall the lake Sediment $0.3912 \mu \mathrm{g} / \mathrm{g}$, while the annual average concentration overall Drains Sediment $0.498 \mu \mathrm{g} / \mathrm{g}$ (Table 8).

Dissolved Lead (D-Pb): Dissolved lead concentrations of the Lake Sediment was ranged between $(11.41-78.4 \mu \mathrm{g} / \mathrm{g})$, with annual average concentration overall the 
lake Sediment $30.781 \mu \mathrm{g} / \mathrm{g}$, while the annual average concentration overall Drains Sediment $73.586 \mu \mathrm{g} / \mathrm{g}$ (Table 8).

Dissolved Mercury (D-Hg): Dissolved Mercury concentrations of the Lake Sediment was ranged between $(0.013-0.231 \mu \mathrm{g} / \mathrm{g})$, with annual average concentration overall the lake Sediment $0.091 \mu \mathrm{g} / \mathrm{g}$, while the annual average concentration overall Drains Sediment $0.161 \mu \mathrm{g} / \mathrm{g}$ (Table 8).

Table 8. Shows average concentrations of Heavy Metals characteristics for sediment lake

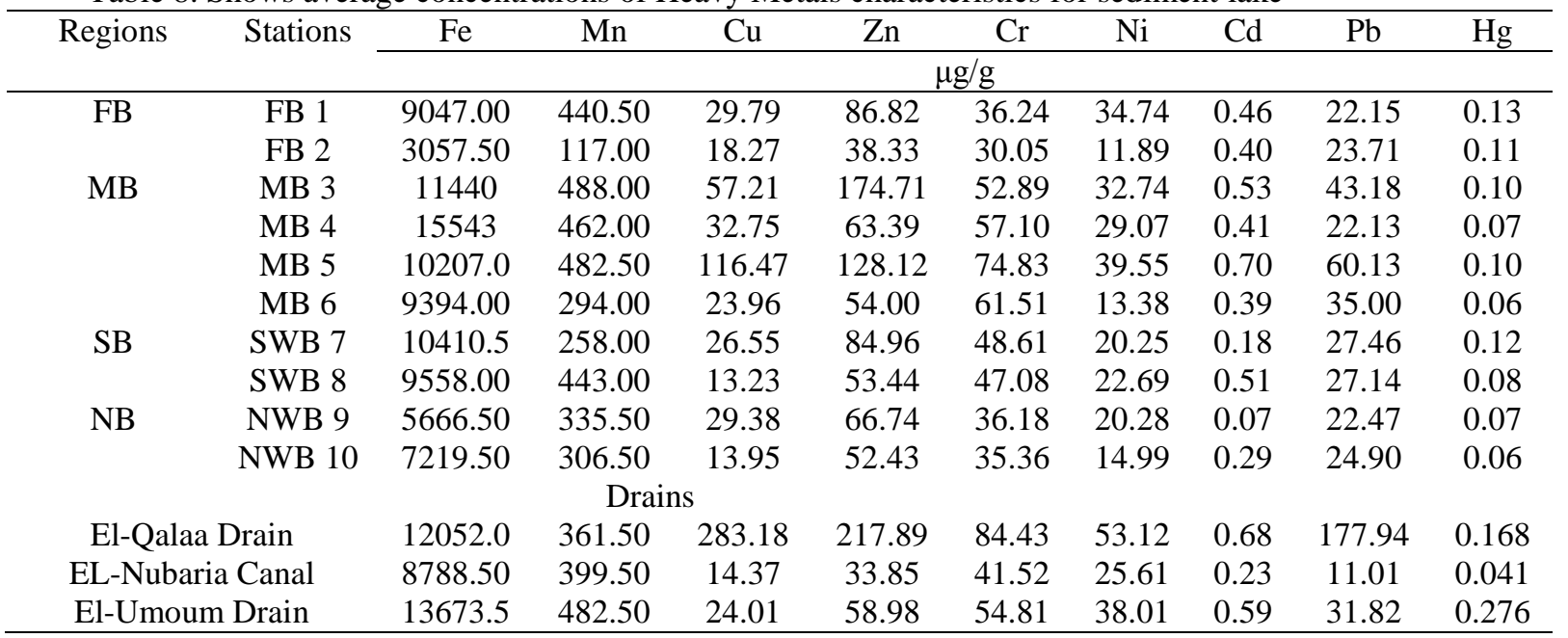

Total pesticides and polychlorinated biphenyls (PCBs) and Petroleum hydrocarbons for Sediment samples

In general, PCBs concentrations of the Lake Sediment was ranged between (0.239 - $1.806 \mathrm{ng} / \mathrm{g})$, with annual average concentration overall the lake Sediment $0.883 \mathrm{ng} / \mathrm{g}$, while the annual average concentration overall Drains Sediment $1.172 \mathrm{n} / \mathrm{g}$ (Table 9).

Table 9: Shows average concentrations Total pesticides\& polychlorinated biphenyls (PCBs) and Petroleum hydrocarbons Parameters for sediment lake

\begin{tabular}{|c|l|c|c|c|}
\hline \multirow{2}{*}{ Regions } & \multirow{2}{*}{ Stations } & PCBs & Total pesticides & $\begin{array}{c}\text { Petroleum } \\
\text { hydrocarbons }(\text { PHC })\end{array}$ \\
\cline { 3 - 5 } & & \multicolumn{3}{|c|}{$\mu \mathrm{g} / \mathrm{g}$} \\
\hline \multirow{2}{*}{ FB } & FB 1 & 0.7615 & 0.5645 & 1.222 \\
\cline { 2 - 5 } & FB 2 & 0.8925 & 0.5625 & 0.889 \\
\hline \multirow{3}{*}{ MB } & MB 3 & 0.8995 & 0.549 & 1.0415 \\
\cline { 2 - 5 } & MB 4 & 1.1705 & 0.488 & 1.3465 \\
\cline { 2 - 5 } & MB 5 & 1.049 & 0.547 & 0.8055 \\
\cline { 2 - 5 } & MB 6 & 0.8105 & 0.528 & 0.608 \\
\hline \multirow{2}{*}{ SB } & SWB 7 & 1.012 & 0.583 & 0.5735 \\
\cline { 2 - 5 } & SWB 8 & 1.0515 & 0.5985 & 0.5695 \\
\hline \multirow{2}{*}{ NB } & NWB 9 & 0.4935 & 0.531 & 0.494 \\
\cline { 2 - 5 } & NWB 10 & 0.6965 & 0.6085 & 1.232 \\
\hline \multicolumn{6}{|l|}{ Dl-Qalaa Drain } & 0.95 & 1.06 & 1.44 \\
\hline \multicolumn{2}{|l|}{ EL-Nubaria Canal } & 1.32 & 0.75 & 1.12 \\
\hline El-Umoum Drain & 1.25 & 0.86 & 1.18 \\
\hline
\end{tabular}

While Total pesticides concentrations of the Lake Sediment was ranged between $(0.266-0.859 \mathrm{ng} / \mathrm{g})$, with annual average concentration overall the lake 
Sediment $0.556 \mathrm{ng} / \mathrm{g}$, while the annual average concentration overall Drains Sediment $0.89 \mathrm{ng} / \mathrm{g}$, (Table 9) and for Petroleum hydrocarbons concentrations of the Lake Sediment was ranged between $(0.180-2.36 \mu \mathrm{g} / \mathrm{g})$, with annual average concentration overall the lake Sediment $0.878 \mu \mathrm{g} / \mathrm{g}$, while the annual average concentration overall Drains Sediment $1.25 \mu \mathrm{g} / \mathrm{g}$ (Table 9).

\section{DISCUSSION}

\section{Water Quality}

The transparency values were related with the location of the stations where the lowest value was registered in station MB3 which located in the front of El-Qalaa drain which loaded with different pollutants; also these values were Compatible with BOD \& COD and TSM values, These results correspond to study carried by (ElShorbagi, 2015; Miguel, 2009), but Temperatures were clearly influenced by weather conditions and the result data were clearly compatible with them, These results correspond to study carried by (El-Shorbagi, 2015; Miguel, 2009), There was a clear correlation between the electrical conductivity and salinity values. The lowest values were recorded at the same station MB3 which located in the front of El-Qalaa drain, which loaded with industrial and sewage wastewater, however, all $\mathrm{pH}$ values were suitable for living organisms, as the EU sets $\mathrm{pH}$ protection limits of 6 to 10 for fisheries and aquatic life (El-Shorbagi, 2015).

The dissolved oxygen (Do) values were affected by the values of BOD \& COD values, were the lower values of Do related to the highest value of BOD and COD which register in station MB3 which located in the front of El-Qalaa drain, which loaded with industrial and sewage waste, In general, the high DO values found in winter due to rough weather and winds occurred during winter, these results correspond to study carried by (El-Shorbagi, 2015), while the higher values of BOD and COD recorded at stations MB3 due to the effect of wastewater discharged from El-Qalaa Drain, which consists of a mixture of East Treatment Plant (ETP) effluent, raw wastewater, irrigation drainage, and runoff, these results correspond to study carried by (El-Shorbagi, 2015; EEAA, 2016).

The concentrations of TSM may affect the physical and chemical properties of aquatic system, as well as many biological implications (Harris, 1972), so the higher values were recorded at stations MB3 which effected by wastewater discharged from El-Qalaa Drain, also The concentrations of Nutrient salts was recorded higher concentrations at stations MB3 due to the effect of wastewater discharged from ElQalaa Drain, which in turn leads to depletion of oxygen contents at these stations, these results correspond to study carried by (El-Shorbagi, 2015; EEAA, 2016).

Heavy Metals data show that there was no higher concentrations recorded in the water samples (lake - drains) where the annual mean average not Exceeded of 50 $\mu \mathrm{g} / \mathrm{m}^{3}$,during the study period, except concentration of Manganese which registered high concentrations at only station MB3 which affected by discharged from El-Qalaa Drain which loaded with industrial and sewage waste, also iron was recorded high concentrations of average annual in all stations and it may be due to the solubility of iron from the lake and drain sediments, which consider the main source of the iron element, these results correspond to study carried by (El-Shorbagi, 2015; Khalifa, 2013; Ranya et al., 2013; EEAA, 2016).

Bacteria contamination data show that the highest concentration of bacteria was recorded at Station MB6 and El-Qalaa drain (which loaded with all types of contaminants). Although the station MB6 is far from the el Qalaa drain the fishermen 
have been established El-Rishi drain which carries most of El-Qalaa drain water towards Station MB6. So, this reason may be explaining the high concentration of bacterial contamination at this station, so these results correspond to the study carried by (EEAA, 2016).

Polychlorinated biphenyls (PCBS) and pesticides concentration show that there was high concentration recorded at station NWB10 in the annual average, this may be due to registration of high concentrations during February 2016, In spite of the location of this station far from any sources of agricultural pollution, especially that all concentrations recorded during the study in all stations and all months Does not exceed $6 \mathrm{ng} / \mathrm{l}$ for Poly-chlorinated biphenyls (PCBS) and $4 \mathrm{ng} / \mathrm{l}$ for pesticides, except this station at this month only this may be due to the impact of Nubaria canal on this station in addition to indirect disposal of some of the industrial facilities near to this station, although it was recorded highest concentrations at El-Qalaa drain and these results correspond to study carried by (EEAA, 2016).

Petroleum hydrocarbons concentrations show that Concentration values were Compatible with the other measurements recorded during the study, the highest concentrations were recorded at station MB3 which located in front of the El-Qalaa drain.

\section{Sediment Quality:}

The results of the monitoring data in the study show that organic carbon and organic content in bottom sediments are more valuable in front of drains and in areas characterized by increasing of mud have coarse grain sizes of sediment $\&$ have and increasing in-depth as it found the areas of the central lakes and it was decreased in areas characterized by fine grain sizes of sediment $\&$ increasing of sand and Areas of water currents (EEAA, 2011), and water content of the sediments increases in areas characterized by fine grain size sand deep (EEAA, 2011), also, the monitoring data of Lake Maruit sediment are Compatible with the results of the monitoring data of water quality. It was clear as registered most of the high concentration of El-Qalaa drain (water \& sediment), This is Lead to the fact that the main source of pollution in the lake (water \& sediment) was El-Qalaa drain as most of the Concentration values were Compatible with the other measurements recorded during the study and other study registered on lake quality.

\section{CONCLUSION}

It is observed that the concentration of pollutants depends mainly on the location and distance of the station from the drain's outfalls. The results of monitoring Data for water and sediments quality indicate that Maruit lake is still suffering from various types of pollution, especially organic matter (BOD \& COD), nutrients and Some Heavy Metals, especially iron and Manganese Also, the study shows that the main source of this pollution comes from the El-Qalaa drain and the result correspond to previous studies on the lake.

Finally, Lake Maruit was considered a major source of pollution to the Mediterranean Sea through El-Mex Bay, because it receives a huge amount of polluted from El-Qalaa drain, and it can be recommended some solutions aimed at improving the environmental status of Lake Maruit as follows:

Unify the concerned institutions and decisions maker in one institution to consolidate the efforts to improve and develop the management method for the lake. 
Providing the lake with the necessary disinfection equipment, which will be improvement water movement in the lake, led to improving the environmental state in the lake, and increase the area of catchable areas.

Implementation of integrated management projects such as the Manzala Lake Project.

Prevent any sources of untreated industrial drainage (directly -indirectly).

Complete rehabilitation of the Eastern and Western sewage treatment plant and delivery of sewage net for all the villages located around the lake.

Prevent acts of reclamation inside the lake.

Work on cultivating local plant species in the purification of the lake from heavy metals pollution with Safe disposal.

\section{REFERENCES}

American Public Health Associations (APHA). (1995). Standard methods for the examination of water and wastewater, 19th edition, New York.

Amr, H.M.; El-Tawila, M.M. and Ramadan, M.H. (2005). Assessment of pollution levels in fish and water of main basin, Lake Mariut. Egypt Public Health Assoc., 80 (1-2):51-76.

Azemared, S. and Coquery, M. (1997). Standard operating procedures for trace metals determination IAEA, Monaco Environmental Laboratory. training workshop on the analysis of trace metals in biological and sediment samples for med pol, MC-98000: 1-42.

EEAA. (2011). Abstract of Annual Report (2010-2011) For the environmental program of the Egyptian lakes (Lake Maruit), 1:1-14.

EEAA. (2016). Abstract of Annual Report (2015-2016) For the environmental program of the Egyptian lakes (Lake Maruit), 4: 1-17.

El-Shorbagi, E.Kh. (2015). Physico-chemical and environmental studies on lake mariut, Egypt. M.Sc. thesis in Chemistry, Fac. Sci. Alexandria Univ., 1-188.

Grasshoff, K.; Ehrhardt, M. and Kremling, K. (1999). Methods of Sea Water Analysis. 3rd Ed., Wiley-VCH, pp632.

Harris, J.E. (1972). Characterization of Suspended Matter in The Gulf of Mexico. I.Spatial distribution of suspended matter. Deep Sea Research, 19: 719 - 726.

Intergovernmental Oceanographic Commission, (IOC). (1983). "Nutrient Analysis in Tropical Marine Waters" Manuals and Guides, UNESCO (28): 1-24.

ISO method (International Organization for Standardization) 5667/9. (1992). Water quality - Sampling - part 9: Guidance on sampling from marine waters, Technical Report, Geneva, Switzerland, 1-6.

Kamal, H.S. and Magdy, T.K. (2005). Socioeconomic features. In: Kamal, H.S., Magdy, T.K. (Eds.), Lake Burullus (Burullus Protected Area). Publication of National Biodiversity Unit, Cairo, pp578.

Khalifa, M. Mohammed, K. Ruslan, V. (2013). Detect Risk Zone of Heavy Metals Contamination in Water of The Lake Mariut, Alexandria, Egypt. Yestestvennye Nauki (Natural Sciences), 2 (43): 73-78.

Koroleff, F. (1971). The determination of reactive silicate in natural waters. Institute of Marine Research Helsinki, Finland, C.M.1971/C, 43: 1-4.

Miguel, Ángel, Mateo. (2009). Lake Mariut: An Ecological Assessment. 32-58.

Mohamed, H. H. and Amaal, M. Abdel-Satar. (2017). Present Status and Long-Term Changes of Water Quality Characteristics in Heavily Polluted Mediterranean Lagoon, Lake Mariut, Egypt, Journal of Applied Science, 3 (4): pp.66. 
Mohammed, K.M. and Ruslan, K. (2013). Detect risk zone of heavy metals contamination in water of the Lake Mariut, Alexandria, Egypt. Nature Sciences, 2 (43): $72-81$.

National Institute of Oceanography and Fisheries (NIOF). (2008). Lake Mariout Data Acquisition Repot Submitted to ALAMIM "Alexandria Lake Mariout Integrated Management', Alexandria, Egypt, 67-68.

Oregioni, B. and Aston, S. (1984). Determination of selected trace metals in marine sediments by flame/flameless atomic absorption spectrophotometer, IAEA Monaco Laboratory Internal Report, Now cited in reference method in pollution studies No. 38, UNEP, 1986.

Parsons, T. R.; Matia Y. and Malli G. M. (1985). Determination of Petroleum Hydrocarbons. A Manual of Chemical and Biological Method for Seawater Analysis, Pergamon Press, Oxford, 1-78.

Ranya, A.; Howaida, H.; Hanan, Gh. and Soraya, S. (2013). Nickel biosorption by alkalitolerant Exiguobacterium sp. 27 isolated from lake Mariout, Egypt, Life Science Journal, 10 (4): 1338-1347.

Riley, J.P. and Taylor, D. (1968). Chelating Resins for the Concentration of Trace Elements from Sea Water and Their Analytical Use in Conjunction with Atomic Absorption Spectrophotometry, Analytica chimica Acta., 40: 479-485.

Saad, M.A. (2003). Impact of diffuse pollution on the Socio-economic development opportunities in the coastal Nile Delta Lakes, Diffuse Pollution and Basin Management. Proceedings of the 7th International Specialised IWA Conference, Dublin, Ireland. ISBN 1902277767, 4vols, 81-85.

Samir, M. and Ibrahim, M. (2008). Assessment of heavy metals pollution in water and sediments and their effect on Oreochromisniloticus in the northern delta lakes, Egypt. $8^{\text {th }}$ International Symposium on Tilapia in Aquaculture. Cairo, 12/14-10, 475-490.

Strickland, J.D. and Parsons, I.R. (1972). A Practical Handbook of Sea Water Analysis. Fish. Res. Bd. 2nd edition, Canada, Bull., 167: pp310.

UNEP/IOC/IAEA. (1992). "Determination of petroleum hydrocarbons in sediments: Reference Methods for Marine Pollution Studies 20", UNEP, pp75.

Welch, P.C. (1952). Limnology, 2nd Ed., London McGraw- Hill Book Co., Inc. N.Y. Toronto, New York, pp538. 